\title{
MANAJEMEN RISIKO PEMBIAYAAN IJARAH PADA KOPERASI SYARIAH PILAR MANDIRI SURABAYA 1]
}

\author{
Ahmad Asy'fin Basthomi \\ Mahasiswa Program Studi S1 Ekonomi Islam-Fakultas Ekonomi dan Bisnis-Universitas Airlangga \\ Email: ahmad.asyfin-12@feb.unair.ac.id \\ Achsania Hendratmi \\ Departemen Ekonomi Syariah-Fakultas Ekonomi dan Bisnis-Universitas Airlangga \\ Email: achsania.hendratmi@feb.unair.ac.id
}

\begin{abstract}
:
Sharia Financial Institution especially Sharia Cooperative needs a series of procedure and methodology which can be used to identify, measure, mitigate and supervise the risk that will be appear from business activity as well as in ljara financing channeled. A series of procedures are known as risk management. The purpose of this study is to know and analyze how management process does on Sharia Cooperative of Pilar Mandiri Surabaya. This study uses qualitative approach with case study method. Data collection techniques uses direct interview technique to the related objects. The result of this study shows that Sharia Cooperative of Pilar Mandiri performed risk management process on the identification, mitigation, assessment or measurement and risk controlling stage. The major risk focus is financing risk that members or prospective members have congestion or failure about meet the financing payment obligation.
\end{abstract}

Keywords : Risk Management, Risk, Financial, ljara, Sharia Cooperative

\section{PENDAHULUAN}

Latar Belakang

Seiring dengan situasi lingkungan eksternal dan internal lembaga keuangan syariah yang mengalami perkembangan pesat, Lembaga Keuangan Syariah akan selalu berhadapan dengan berbagai jenis risiko dengan tingkat kompleksitas yang beragam dan melekat pada kegiatan usahanya (Karim, 2014 : 255). Maka lembaga keuangan syariah juga memerlukan prosedur untuk meminimalisir risiko yang disebut dengan manajemen risiko.

Beberapa langkah dalam proses manajemen risiko adalah mengidentifikasi risiko, menganalisis nilai risiko tersebut, memilih teknik yang sesuai untuk menangani risiko yang ada, dan mengimplementasikan dan mengawasi 1) Jurnal ini merupakan bagian dari skripsi dari Ahmad Asy'fin Basthomi. NIM 041211433047 yang diuji pada 8 Februari 2017

manajemen risiko. Manajemen risiko tersebut diaplikasikan untuk menjaga agar aktifitas Lembaga Kevangan Syariah tidak mengalami kerugian yang melebihi batas kemampuan yangdapat membahayakan kelangsungan dan kesehatan Lembaga Kevangan Syariah. Penanganan risiko lebih pada antisipasi atas apa yang akan terjadi (Rejda, 2008:43).

Kebutuhan untuk mengelola resiko secara sistematis berlaku bagi setiap organisasi dan individu. Demikian juga halnya bagi setiap fungsi dan kegiatan di dalam perusahaan. Manajemen resiko membantu suatu entitas untuk mencapai target kinerja dan profitabilitas, serta mencegah terjadinya kerugian sumber daya. Manajemen resiko membantu terwujudnya pelaporan yang efektif, kepatuhan terhadap hukum dan 
peraturan yang berlaku, mencegah kerusakan reputasi perusahaan dan konsekuensi-konsekuensi lainnya. Secara singkat, manajemen resiko membantu perusahaan mencapai tujuan yang diinginkannya dan terhindar dari berbagai jebakan dan kejutan di sepanjang perjalanan menuju tujuan tersebut (Alijoyo, 2006: 6).

Pada Koperasi Syariah terdapat beberapa akad pada pembiayaannya, akad tersebut meliputi mudharabah, musyarakah, murabahah, ijarah, ijarah muntahiya bittamlik, rahn, istishna', dsb. Pengertian ijarah adalah akad pemindahan hak guna atas barang dan jasa, melalui pembayaran upah sewa, tanpa diikuti dengan pemindahan kepemilikan atas barang itu sendiri (Sudarsono, 2004 : 66).

Pembiayaan ijarah sebenarnya dapat dikatakan lebih menarik dibandingkan jenis pembiayaan lainnya, karena pembiayaan ijarah mempunyai keistimewaan bahwa untuk memulai kegiatan usaha, pengusaha tidak perlu memiliki barang modal terlebih dahulu, melainkan dapat melakukan penyewaan kepada Lembaga keuangan syariah. (Purnomo, 2016)

Menurut Hasanah dkk (2015) penelitiannya pada salah satu koperasi syariah di Indonesia menyebutkan bahwa risiko yang sering terjadi pada pembiayaan di koperasi syariah adalah risiko yang terkait dengan sistem pembayaran yaitu pembayaran kurang lancar dari anggota karena terjadi risiko murni yang dialami oleh anggota.

Sedangkan menurut (Antonio, 2001: 119) risiko yang mungkin terjadi dalam alijarah adalah sebagai berikut : Default, nasabah tidak membayar cicilan dengan sengaja; Rusak, asset ijarah rusak sehingga menyebabkan biaya pemeliharaan bertambah, terutama bila disebutkan dalam kontrak bahwa pemeliharaan harus dilakukan oleh LKS; Berhenti, nasabah berhenti di tengah kontrak dan tidak mau membeli asset tersebut. Akibatnya, LKS harus menghitung kembali keuntungan dan mengembalikan sebagian kepada nasabah.

Koperasi Syariah Pilar Mandiri Nurul Hayat merupakan Koperasi Syariah yang didirikan atas inisiasi Yayasan Nurul Hayat dengan tujuan menjadi gerakan ekonomi rakyat serta ikut membangun tatanan perekonomian nasional.

Pada Koperasi Syariah Pilar Mandiri Surabaya, pembiayaan ijarah menempati jumlah terbanyak kedua setelah pembiayaan qordhul hasan. Sampai bulan September 2016, jumlah anggota yang diberikan pembiayaan qordhul hasan sebesar 444 anggota, pembiayaan ijarah sebesar 343 anggota, pembiayaan murabahah sebesar 25 anggota, pembiayaan mudharabah sebesar 6 anggota. Namun pada pembiayaan tersebut, pembiayaan produktif paling banyak dilakukan menggunakan akad ijarah.

Hasil rekap NPF (non performing financing) Koperasi Syariah Pilar Mandiri 
menyatakan bahwa pada September 2016, dari 343 anggota yang diberikan pembiayaan ljarah, 40 anggota mengalami pembiayaan kurang lancar dengan jumlah Rp. 20.583.576.18 anggota mengalami pembiayaan yang diragukan dengan jumlah Rp. 31.505.562.117 anggota mengalami pembiayaan macet dengan jumlah Rp. 636.367.989. Jadi pembiayaan non lancar pembiayaan ijarah sejumlah 175 anggota dengan jumlah Rp. 688.457.129. Dari jumlah outstanding Rp. 1.586.376.747, NPF (non performing financing) pembiayaan ijarah sebesar $43,40 \%$. Dari data tersebut nilai NPF jauh melebihi batas toleransi NPF yang ditentukan oleh Otoritas Jasa Keuangan Nomor 29/POJK.05/2014 tentang penyelenggaraan usaha perusahaan pembiayaan yakni sebesar $5 \%$. Maka dari itu perlu adanya manajemen risiko yang baik untuk meminimalisir risiko serta menekan angka NPF.

\section{LANDASAN TEORI}

\section{Koperasi Syariah}

Menurut UU No 25 Tahun 1992, Koperasi adalah badan usaha yang beranggotakan orang-seorang atau badan hukum Koperasi dengan melandaskan kegiatannya berdasarkan prinsip Koperasi sekaligus sebagai gerakan ekonomi rakyat yang berdasar atas asas kekeluargaan. Nawawi (2009: 108) mengemukakan bahwa mendirikan koperasi dibolehkan menurut agama Islam tanpa ada keragu-raguan apa pun mengenai halnya, selama koperasi tidak melakukan riba atau penghasilan haram.

Sebagian ulama menyebut koperasi dengan syirkah Ta'awuniyah (Persekutuan tolong-menolong) yaitu, suatu perjanjian kerjasama antara dua orang atau lebih, yang satu pihak menyediakan modal usaha, sedangkan pihak lain melakukan usaha atas dasar profit sharring (membagi untung) menurut perjanjian (Suhendi, 2002: 291).

Koperasi Simpan Pinjam dan Pembiayaan Syariah menurut Peraturan Menteri Koperasi dan Usaha Kecil dan Menengah Republik Indonesia Nomor 16/Per/M.KUKM/IX/2015 adalah Koperasi Simpan Pinjam dan Pembiayaan Syariah selanjutnya dalam peraturan ini disebut KSPPS adalah koperasi yang kegiatan usahanya meliputi simpanan, pinjaman dan pembiayaan sesuai prinsip syariah, termasuk mengelola zakat, infaq/sedekah, dan wakaf.

\section{ljarah}

Al-ijarah adalah akad pemindahan hak guna atas barang atau jasa, melalui pembayaran upah sewa, tanpa diikuti dengan pemindahan kepemilikan (ownership/milkiyyah) atas barang itu sendiri (Antonio, 2001: 117).

Hukum ljarah dibolehkan dengan adanya dalil dari Al-Quran, Al-Hadits, dan ijma ulama. Manusia bebas untuk saling berinteraksi dalam hal muamalah selama hal tersebut tidak bertentangan dengan Syariat islam. Dalil disyariatkan ijarah adalah Surat Al-Baqarah ayat 233. 


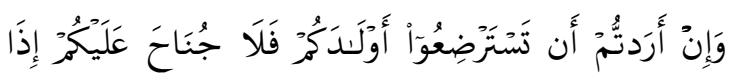

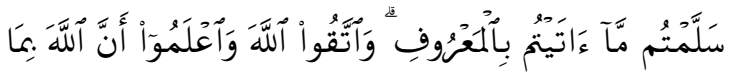
تَعْمَلُونَ بَصِيرِ

Wa In Aradtum An Tastardhi'ū Awlādakum Falā Junāha `Alaykum Idzā Sallamtum Mā Ātaytum Bil-Ma'rūfi Wa Attaqū Allaha Wa A lamū 'Anna Allāha Bimā Ta`malūna Bashirun

Artinya : dan jika kamu ingin anakmu disusukan oleh orang lain, Maka tidak ada dosa bagimu apabila kamu memberikan pembayaran menurut yang patut. bertakwalah kamu kepada Allah dan ketahuilah bahwa Allah Maha melihat apa yang kamu kerjakan.

Menurut (Ascarya, 2007: 99) Ada dua jenis ijarah dalam hukum Islam, yaitu :

1. ljarah yang berhubungan dengan sewa jasa, yaitu mempekerjakan jasa seseorang dengan upah sebagai imbalan jasa yang disewa. Pihak yang mempekerjakan disebut musta'jir, pihak pekerja disebur ajir, upah dibayarkan disebut ujrah.

2. ljarah yang berhubungan dengan sewa asset atau property, yaitu memindahkan hak untuk memakai dari asset atau property tertentu kepada orang laindengan imbalan biaya sewa. Bentuk ijarah ini mirip dengan leasing (sewa) di bisnis konvensional. Pihak yang menyewa (lesse) disebut musta'jir, pihak yang menyewakan (lessor) disebut mu'jir/muajir, sedangkan biaya sewa disebut ujrah.

\section{Pembiayaan ljarah}

Ascarya (2007: 101) menjelaskan dua hal yang harus diperhatikan dalam penggunaan ijarah sebagai bentuk pembiayaan. Pertama, beberapa syarat harus dipenuhi agar hukum-hukum Syariah terpenuhi, dan yang pokok adalah:

1. Jasa atau manfaat yang akan diberikan oleh asset yang disewakan tersebut harus tertentu dan diketahui dengan jelas oleh kedua belah pihak;

2. Kepemilikan asset tetap pada yang menyewakan yang bertanggung jawab atas pemeliharaannya sehingga asset tersebut terus dapat memberi manfaat kepada penyewa;

3. Akad ijarah dihentikan pada saat asset yang bersangkutan berhenti memberikan manfaat kepada penyewa. Jika asset tersebut rusak dalam periode kontrak, akad ijarah masih tetap berlaku; dan

4. Asset tidak boleh dijual kepada penyewa dengan harga yang ditetapkan sebelumnya pada saat kontrak berakhir. Apabila asset akan dijual, harganya akan ditentukan pada saat kontrak berakhir.

\section{Risiko}

Risiko adalah fungsi dari atau berhubungan dengan berbagai ketidakpastian dan tingkat eksposur suatu entitas terhadap ketidakpastian tersebut. Semakin tinggi tingkat ketidakpastian dan 
eksposur yang dihadapi suatu organisasi, semakin tinggi pula konsekuensi dan kemungkinan terjadinya (Alijoyo, 2006: 6).

Bringham dan Houston (2001:178) berpendapat bahwa risiko adalah peluang bahwa beberapa kejadian yang tidak menguntungkan akan terjadi. Risiko dihubungkan dengan probabilitas suatu kejadian. Probabilitas merupakan peluang bahwa suatu kejadian akan terjadi.

Islam memandang bahwa risiko merupakan sebuah sunnatullah dalam sebuah bisnis. Manusia hanya dapat memprediksi berdasarkan pengamatannya, termasuk memprediksi kerugian yang mungkin terjadi di masa depan. Dalam usahanya mencari nafkah, manusia dihadapkan pada kondisi yang tidak pasti. Manusia bisa merencakana setiap kegiatan usaha maupun investasi apa saja yang akan dilakukan, namun manusia tidak bisa memastikan atas hasil yang didapatkan dari usaha maupun invetasi tersebut apakah untung maupun rugi.

Risiko merupakan suatu kejadian potensial, baik yang dapat diperkirakan maupun yang tidak dapat diperkirakan yang berdampak negative terhadap pendapatan dan permodalan. Esensi dari penerapan manajemen risiko adalah kecukupan prosedur dan metodologi pengelolaan risiko sehingga kegiatan usaha tetap terkendali pada batas yang dapat diterima serta menguntungkan (Rivai, 2008: 623).

\section{Manajemen Risiko}

Manajemen risiko didefinisikan sebagai suatu metode logis dan sistematik dalam identifikasi, kuantifikasi, menentukan sikap, menetapkan solusi, serta melakukan monitor dan pelaporan risiko yang berlangsung pada setiap aktivitas atau proses (Idroes, 2008: 5).

Dalam perspektif Islam, manajemen risiko merupakan usaha untuk menjaga amanah Allah akan harta kekayaan demi untuk kemaslahatan manusia. Keberhasilan manusia dalam mengelola risiko, bisa mendatangkan maslahat yang lebih baik. Dengan timbulnya kemaslahatan ini maka bisa dimaknai sebagai keberhasilan manusia dalam menjaga amanah Allah.

Tujuan manajemen risiko secara umum adalah untuk menghindari risiko sebelum terjadinya kerugian (preloss objectives) dan mengatasi risiko setelah terjadinya kerugian (postloss objectives) (Siahaan, 2007:315).

Proses Manajemen Risiko

Idroes (2008: 7) mengemukakan bahwa tindakan berkesinambungan yang dilakukan sejalan dengan definisi menajemen risiko yang telah dikemukakan, yaitu identifikasi, kuantifikasi, menentukan sikap, menetapkan solusi, serta melakukan monitor dan pelaporan risiko.

Identifikasi risiko yang dilakukan dalam Lembaga Keuangan Syariah juga meliputi berbagai risiko yang khas pada Lembaga Keuangan Syariah. Dalam hal ini, keunikannya terletak pada enam hal: pertama, proses transaksi pembiayaan. 
Basthomi, et al/Jurnal Ekonomi Syariah Teori dan Terapan Vol. 4 No. 7 Juli 2017: 547-559; MANAJEMEN RISIKO PEMBIAYAAN IJARAH PADA KOPERASI SYARIAH PILAR MANDIRI SURABAYA

Kedua, proses manajemen. Ketiga, sumber daya manusia. Keempat, teknologi. Kelima, lingkungan eksternal. Keenam, kerusakan. Dalam penilaian risiko, keunikaanya terlihat pada hubungan antara probability dan impact, yang biasa dikenal sebagai Qualitative Approach. Sedangkan antisipasi risiko lembaga keuangan syariah bertujuan untuk: preventive, detective, dan recovery. Untuk aktivitas monitoring dalam lembaga keuangan syariah tidak hanya meliputi manajemen lembaga keuangan syariah, tetapi juga melibatkan Dewan Pengawas Syariah (Karim, 2014: 256-258).

\section{METODE PENELITIAN}

\section{Pendekatan Penelitian}

Pendekatan yang digunakan dalam penelitian ini adalah pendekatan kualitatif. Penelitian ini menggunakan penelitian kualitatif karena untuk menjawab pertanyaan penelitian yang terdapat pada rumusan masalah secara komprehensif dan mendalam, yaitu bagaimana proses manajemen risiko pembiayaan ijarah pada Koperasi Syariah Pilar Mandiri Surabaya.

Terdapat lima stategi penelitian kualitatif menurut Yin (2009 : 8), yakni eksperimen, survey, analisis arsip, historis, dan studi kasus. Dalam penilitian ini penulis menggunakan strategi studi kasus. Studi kasus adalah inkuiri empiris yang menyelidiki fenomena di dalam konteks kehidupan nyata, bilamana batas-batas antara fenomena dan konteks tak tampak dengan tegas ; dan dimana multisumber bukti dimanfaatkan (Yin, 2009 :18).

\section{Unit Analisis}

Unit analisis dalam penelitian ini adalah proses manajemen risiko pembiayaan ijarah pada Koperasi Syariah Pilar Mandiri Surabaya, serangkaian proses yang dimaksud adalah terdiri dari :

a) Identifikasi Risiko

b) Pengukuran Risiko

c) Mitigasi Risiko

d) Monitoring and Controlling Risk

\section{Ruang Lingkup Penelitian}

Ruang lingkup penelitian dan batasan penelitian ini adalah proses manajemen risiko pembiayaan yang menggunakan akad ijarah pada Koperasi Syariah Pilar Mandiri Surabaya.

\section{Jenis dan Sumber Data}

Sumber dan jenis data dalam penelitian diperoleh dengan cara berikut :

1. Data Primer

Data primer yang dijadikan sumber data dalam penelitian ini adalah wawanacara yang dilakukan pada manajer serta funding offiecer Kopersi Syariah Pilar Mandiri Surabaya.

2. Data sekunder merupakan data yang mendukung penelitian, yang didapatkan secara tidak langsung dari suatu objek penelitian yang berupa arsip, laporan, dan dokumen yang relevan serta kajian pustaka yang berkaitan dengan penelitian (Sugiyono, 2012: 137).

Pertanyaan yang diajukan adalah pertanyaan yang sesuai dengan tujuan 
Basthomi, et al/Jurnal Ekonomi Syariah Teori dan Terapan Vol. 4 No. 7 Juli 2017: 547-559; MANAJEMEN RISIKO PEMBIAYAAN IJARAH PADA KOPERASI SYARIAH PILAR MANDIRI SURABAYA

penelitian, yaitu yang berhubungan dengan proses manajemen risiko pembiayaan ijarah pada Koperasi Syariah Pilar Mandiri Surabaya.

\section{Teknik Pengumpulan Data}

Langkah langkah yang dilakukan dalam prosedur pengumpulan data adalah sebagai berikut:

1. Persiapan Awal

Pada tahap ini, penulis mengurus surat ijin penelitian kepada Fakultas Ekonomi dan Bisnis Universitas Airlangga untuk mewawancarai pihak Koperasi Syariah Pilar Mandiri Surabaya.

2. Penelitian Lapangan

Wawancara dengan pihak Koperasi Syariah Pilar Mandiri Surabaya tentang bagaimana praktek pembiayan ijarah serta bagaimana manajemen risiko pada pembayaan ijarah.

\section{Teknik Keabsahan Data}

Dalam penelitian ini yang digunakan adalah triangulasi dengan sumber data, dengan cara menggali sumber dan mengecek baik derajat kerpecayaan suatu data yang telah diperoleh melalui beberapa sumber. Dalam peneltian ini triangulasi sumber dilakukan dengan jalan membandingkan hasil wawancara dengan isi suatu dokumen yang berkaitan guna memperoleh keterkaitan antar data.

\section{Teknik Analisis}

Untuk mengetahui bagaimana Koperasi Syariah Pilar Mandiri Surabaya ini melakukan proses manajemen risiko pembiayaan ijarah nya, peneliti akan menggunakan teknik pengolahan atau analisis data yang di dapat selama peneliti di lapangan.

\section{HASIL DAN PEMBAHASAN}

Koperasi Syariah Pilar Mandiri Nurul Hayat merupakan Koperasi Syariah yang didirikan atas inisiasi Yayasan Nurul Hayat dengan tujuan menjadi gerakan ekonomi rakyat serta ikut membangun tatanan perekonomian nasional. Fungsi koperasi pun tidak hanya ditujukan untuk karyawan Nurul Hayat, tetapi juga ditujukan untuk kelompok binaan Nurul Hayat dan masyarakat umum yang membutuhkan dana. Adapun kelompok binaan dari Nurul Hayat, seperti SAYANG, ASAH, ASAH PENA, MATABACA, IBUQU, PRAKTIS, SAHABAT, dan lain lain.

Koperasi Jasa Keuangan Syariah Pilar Mandiri Nurul Hayat telah mendapat ijin resmi dari Dinas Koperasi Kota Surabaya nomor badan hukum: 496/BH/XVI.37/2012.

Para informan di dalam penelitian ini adalah manajer, serta 2 orang funding officer atau juga biasa disebut sebagai kolektor. Ketiga informan ini adalah pengurus Koperasi Syariah Pilar Mandiri Surabaya yang berhubungan langsung pada proses manajemen risiko pembiayaan ijarah pada koperasi syariah tersebut. Manajer dipilih sebagai key informan dalam proses penelitian karena manajer adalah orang yang paling paham proses manajemen risiko pembiayan ijarah, 2 orang funding officer sebagai main informan untuk membuktikan keadaan di lapangan bagaimana prosedur pembiayaan ijarah 
serta bagaimana proses manajemen risikonya.

Setiap pembiayaan yang disalurkan memiliki risiko yang terikat, untuk menghindari risiko yang dapat merugikan Koperasi Syariah Pilar Mandiri, Koperasi Syariah Pilar Mandiri melaksanakan fungsi manajemen risiko secara khusus. Proses manajemen risiko tersebut meliputi identifikasi risiko, penilaian risiko, mitigasi risiko serta pengawasan. Proses manajemen risiko dilakukan oleh pengurus koperasi syariah dibantu koordinator anggota binaan. Anggota binaan ini dibagi menjadi beberapa wilayah dengan diketuai oleh koordinator. Koordinator inilah yang bertanggung jawab atas anggotanya. Koordinator juga harus mengetahui kondisi anggotanya, kondisi tersebut meliputi karakter anggota, lingkungan anggota, sifat anggota, dan tempat tinngal anggotanya.

Dalam hal mengidentifikasi risiko, Koperasi Syariah Pilar Mandiri melihat history dari calon nasabah yang akan diberikan pembiayaan, apakah nasabah tersebut sudah menjadi anggota koperasi atau belum, karena pihak koperasi sangat berhati-hati pada anggota baru, karena belum teridentifikasi karakter calon anggota baru. Ketika yang mengajukan pembiayaan tersebut sudah menjadi anggota, maka dilihat apakah anggota tersebut masih memiliki tanggungan atau tidak. Pihak Koperasi Syariah juga melihat track record dari calon penerima pembiayaan, bagaimana pembiayaanpembiayaan yang dilakukan sebelumnya, apakah kondisinya bagus atau sering macet, hal itu juga menjadi pertimbangan pihak Koperasi Syariah. Selain itu identifikasi risiko juga dilakukan dengan cara mencari informasi pada koordinator anggota, karena koordinator tersebut yang mengetahui keseharian dan karakteritik calon anggota. Setelah melihat history dari calon anggota tersebut dari beberapa sumber, yang dilakukan oleh Koperasi Syariah Pilar Mandiri adalah dengan survey langsung ke lapangan tempat tinggal anggota maupun calon anggota yang akan diberikan pembiayaan.

Jadi pada proses identifikasi risiko ini, Koperasi Syariah Pilar Mandiri Surabaya menerapkan beberapa prinsip 5C yakni Character, Capacity, Capital, Condition, Collateral. Namun yang digunakan dan menjadi pertimbangan besar diterimanya pembiayaan yang diajukan oleh anggota atau calon anggota adalah Character, dan Capacity.

Proses selanjutnya adalah penilaian risiko, Koperasi Syariah Pilar Mandiri melakukan penilaian risiko secara sederhana, tidak membuat penilaian risiko secara sistematis menggunakan pendekatan probability dan impact, yang biasa dikenal sebagai Qualitative Approach. Menurut Koperasi Syariah Pilar Mandiri risiko yang paling sering terjadi dan dampaknya besar adalah risiko pembiayaan macet dan gagal bayar. Penilaian risiko tersebut juga didasarkan pada karakteristik anggotanya, apakah anggota tersebut aktif mengikuti kajian 
rutin atau tidak. Koperasi Syariah Pilar Mandiri menilai risiko-risiko yang timbul dari pengajuan pembiayaan tersebut apakah layak atau tidak untuk diberi pembiayaan. Apabila risiko yang ditimbulkan dari suatu pembiayaan masih bisa ditangani maka Koperasi Syariah Pilar Mandiri menyetujui pengajuan pembiayaan tersebut atau sebaliknya.

Koperasi Syariah Pilar Mandiri melakukan proses mitigasi risiko dengan cara penghindaran, pencegahan kerugian, dan juga pengurangan kerugian. Hal tersebut dilakukan sesuai dengan risiko yang dihadapi, dengan cara memperkuat fungsi koordinator, memperketat proses pengajuan pembiayaan, dan juga memperbaiki proses identifikasi serta penilaian risiko. Koperasi Syariah Pilar Mandiri melakukan evaluasi rutin yang dilakukan oleh pengurus setiap satu minggu sekali. Menurut manajer Koperasi Syariah Pilar Mandiri, evaluasi ini dilakukan untuk membahas kegiatan yang sudah dilakukan selama satu minggu dan mencari solusi ketika ada permasalahan, kemudian melakukan perbaikan kualitas pengurus dikarenakan sumber daya manusia masih kurang dalam hal jumlah, ilmu dan pengalaman.

Seperti yang disampaikan informan, Koperasi Syariah Pilar Mandiri melakukan proses monitoring dari anggota yang diberikan pembiayaan pada awal diberikannya pembiayaan, apakah sesuai dengan kesepakatan diawal, kemudian monitoring juga dilakukan dengan melihat kelancaran nasabah pada setiap pembayarannya. Ketika terjadi macet ditengah akad, maka akan dilakukan kembali monitoring ke tempat usaha yang dilakukan.

Selain itu, implementasi pengawasan manajemen risiko pembiayaan ijarah dilaksanakan dengan evaluasi mingguan. Evaluasi mingguan ini diikuti oleh seluruh pengurus Koperasi Syariah Pilar Mandiri. Evaluasi tersebut dilaksanakan untuk memastikan bahwa semua kegiatan pembiayaan telah dilaksanakan dengan baik. Dalam evaluasi mingguan ini dilakukan penjabaran masalah-masalah yang dihadapi dalam seminggu, dan selanjutnya pengurus akan mencari solusi bagaimana menangani masalah-masalah tersebut. Evaluasi juga dilakukan dengan yayasan Nurul Hayat setiap satu minggu sekali. Evaluasi ini diikuti oleh manajer Koperasi Syariah Pilar Mandiri. Evaluasi ini membahas progress atau perkembangan dari Koperasi Syariah Pilar Mandiri.

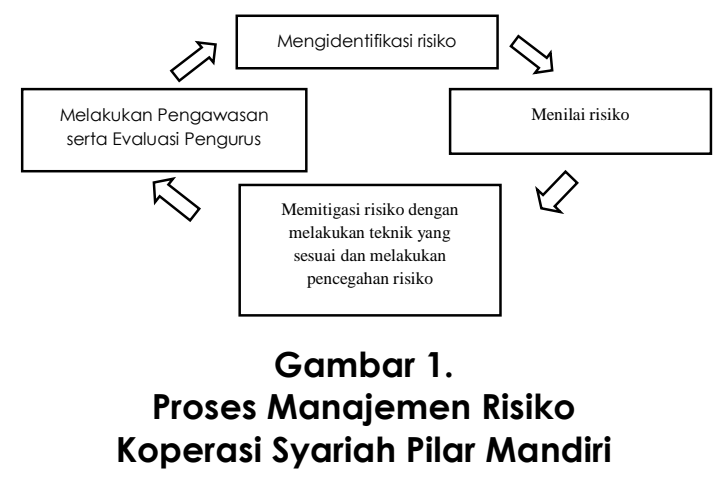

Dari ketiga informan dapat disimpulkan bahwa risiko pembiayaan ijarah paling besar terletak pada ketidakmampuan anggota dalam menyelesaikan pembiayaan, terlebih lagi 
Basthomi, et al/Jurnal Ekonomi Syariah Teori dan Terapan Vol. 4 No. 7 Juli 2017: 547-559; MANAJEMEN RISIKO PEMBIAYAAN IJARAH PADA KOPERASI SYARIAH PILAR MANDIRI SURABAYA

apabila anggota tersebut mengalami gagal bayar. Salah satu penyebab risiko tersebut timbul adalah anggota yang diberikan pembiayaan ijarah mengalami kelesuan usaha yang dilakukan, akibatnya anggota tersebut tidak bisa memenuhi kewajibannya pada Koperasi Syariah Pilar Mandiri secara lancar, selain itu penyebab risiko tersebut timbul akibat anggota maupun calon anggota mengalami sakit, sehingga tidak dapat menjalankan usahanya. Akibatnya anggota ataupun calon anggota tersebut tidak bisa memenuhi kewajibannya pada Koperasi Pilar Mandiri Surabaya.

Untuk risiko rusaknya asset ijarah, pihak Koperasi Syariah Pilar Mandiri belum pernah mengalaminya. Seperti yang disampaikan Bapak Imam manajer Koperasi Syariah Pilar Mandiri sebagai berikut.

"selama ini belum pernah terjadi, namun kadang kerusakan2 kecil mereka benahi sendiri."

Divisi yang bertanggung jawab pada penanganan risiko pembiayaan ini adalah divisi marketing. Divisi ini bertanggung jawab atas semua pembiayaan yang dikeluarkan oleh Koperasi Syariah Pilar Mandiri serta kelancaran pembayaran angsuran oleh angggota atau calon anggota pembiayaan. Selain divisi marketing yang bertanggung jawab atas kelancaran pembayaran angsuran oleh angggota atau calon anggota pembiayaan.adalah koordinator. Karena koordinator bertanggung jawab atas anggotanya, bagaimana pembiayaan yang dilakukan oleh anggotanya, bagaimana kelancaran pembayaran angsuran anggotanya.

Adapaun cara yang dilakukan Koperasi Syariah Pilar Mandiri untuk memitigasi risiko kegagalan anggota atau calon anggota pembiayaan dalam memenuhi kewajiban untuk membayar angsuran pembiayaan adalah sebagai berikut :

1. Koperasi Syariah Pilar Mandiri meneliti kelayakan anggota atau calon anggota pembiayaan dengan melihat karakteristiknya. Koordinator melakukan survey dilanjutkan dengan divisi marketing, dengan mewawancarai anggota atau calon anggota pembiayaan ijarah secara mendalam.

2. Setiap anggota dianjurkan untuk mengikuti kajian rutin yang diadakan Nurul Hayat, karena hal itu menjadi salah satu indikator diterimanya pengajuan pembiayaan.

3. Pengurus Koperasi Syariah Pilar Mandiri melakukan pendekatan personal kepada anggota atau calon anggota.

Implementasi

pengawasan manajemen risiko pembiayaan ijarah dilaksanakan dengan evaluasi mingguan. Evaluasi mingguan ini diikuti oleh seluruh pengurus Koperasi Syariah Pilar Mandiri. Evaluasi tersebut dilaksanakan untuk memastikan bahwa semua kegiatan pembiayaan telah dilaksanakan dengan baik. 


\section{SIMPULAN}

Dari hasil pembahasan di atas, penulis mengambil beberapa kesimpulan mengenai proses manajemen risiko pembiayaan ijarah pada Koperasi Syariah Pilar Mandiri Surabaya. Kesimpulan tersebut diantaranya adalah :

1. Koperasi Syariah Pilar Mandiri Surabaya melakukan proses manajemen risiko diawali dengan proses identifikasi risiko dengan cara melihat data history dan track record anggota atau calon anggota melalui berbagai sumber. Selain itu juga melihat karakteristik anggota atau calon anggota melalui koordinator wilayah, dan divalidasi oleh pengurus Koperasi Syariah melalui survey. Koperasi Syariah Pilar Mandiri Surabaya menerapkan beberapa prinsip 5C yakni Character dan Capacity pada tahap identifikasi risiko.

2. Untuk penilaian risiko, pihak Koperasi Syariah Pilar Mandiri belum membuat penilaian risiko dengan pendekatan probability dan impact, namun risiko yang paling diwaspadai oleh Koperasi Syariah Pilar Mandiri adalah risiko pembiayaan (pembiayaan macet dan gagal bayar). Pada Koperasi Syariah Pilar Mandiri Surabaya risiko yang memiliki dampak besar dengan intensitas terjadinya sering adalah risiko pembiayaan yang disebabkan oleh pembiayaan yang disalurkan kepada anggota binaan.
3. Pada tahap mitigasi risiko, Koperasi Syariah Pilar Mandiri memperkuat fungsi koordinator, memperketat proses pengajuan pembiayaan, memperbaiki proses identifikasi, meminimalisir adanya kekurangan saat proses identifikasi, serta melakukan analisis $5 \mathrm{C}$ sebelum menyetuji pembiayaan yakni Caracter dan Capacity. Selain itu pengurus Koperasi Syariah Pilar Mandiri melakukan edukasi kepada anggota atau calon anggota melalui kajian rutin yang dilakukan oleh yayasan Nurul Hayat. Dan pada tahap mitigasi risiko juga dilakukan pendekatan personal serta menjalin silaturahmi yang baik antara pengurus Koperasi Syariah Pilar Mandiri kepada anggota atau calon anggota.

4. Koperasi Syariah Pilar Mandiri melakukan pengawasan hanya pada awal pembiayaan tersebut dilakukan, dan melihat kelancaran pembayaran setiap bulannya. Selain itu juga diadakan evaluasi pengurus setiap satu minggu sekali. Evaluasi juga dilakukan dengan yayasan Nurul Hayat yang diikuti oleh manajer Koperasi Syariah Pilar Mandiri yang dilakaukan setiap satu minggu sekali.

Saran yang direkomendasikan setelah melakukan penelitian ini adalah sebagai berikut:

1. Bagi Koperasi Syariah Pilar Mandiri Surabaya 
a. Penilitian ini diharapkan dapat memberikan pandangan dan pertimbangan akan proses manajemen risiko yang akan dilakukan. Dan menjadi bahan rujukan akan adanya perbaikan serta pengembangan terhadap proses manajemen risiko

b. Koperasi Syariah Pilar Mandiri hendaknya menambah pengurus bagian analis pembiayaan, memperluas kegiatan usaha, sering melakukan diskusi atau sharing dengan koperasi syariah lain, membuat klausul pembiayaan, meningkatkan pengetahuan dan pemahaman tentang ekonomi syariah, terutama akad-akad pada pembiayaannya.

2. Bagi peneliti selanjutnya

a. Peneliti selanjutnya hendaknya meneliti dengan topik yang sama dengan objek penelitian lebih banyak lagi serta melakukan magang pada objek penelitian agar lebih mengetahui bagaimana proses manajemen risiko pembiayaan ijarah.

\section{DAFTAR PUSTAKA}

Antonio, Muhammad Syafi'i. 2001. Bank syariah: Dari teori ke praktik. Jakarta: Gema Insani.

Alijoyo, Antonius. 2006. Dasar-dasar Entreprises Risk Management untuk direktur dan Komisaris.
Jakarta: Lembaga Komisaris dan Direktur Indonesia.

Ascarya. 2007. Akad \& produk bank syariah. Jakarta. Raja Grafindo Perkasa.

Bringham, Eugene dan Joel F. Houston. 1978. Manajemen keuangan. Edisi ke -8 buku ke -1. Terjemahan oleh Dodo Suharto dan Herman Wilowo. 2001. Jakarta: Erlangga.

Departemen Agama Republik Indonesia. 2006. Al-quran Dan Terjemahannya. Jakarta: CV. Pustaka Agung Harapan.

Hasanah, Nur dkk. 2015. Risiko akad murabahah serta pengelolaan risiko akad murabahah pada BMT-UGT sidogiri cabang wongsorejo, kabupaten banyuwangi. Jurusan manajemen, fakultas ekonomi, universitas jember.

Idroes, Ferry N. 2008. Manajemen risiko perbankan :pemahaman pendekatan 3 pilar kesepakatan basel II terkait aplikasi regulasi dan pelaksanaannya di Indonesia. Jakarta: Rajawali pers.

Karim A, Adiwarman. 2014. Bank Islam: analisis fiqih dan keuangan. Jakarta. PT. Raja Grafindo Persada.

Purnomo, Joko. 2016. Manajemen Risiko Pembiayaan ljarah di Perbankan Syariah. Yogyakarta: Program Studi Hukum Islam Pascasarjana UIN Sunan Kalijaga. 
Redja, George E. 2008. Principles of risk management and insurance. Boston: pearson international edition Edisi ke-10.

Rivai, veithzal, dan andriapermata veithzal. 2008. Islamic financial management: teori, konsep, dan aplikasi (panduan praktis untuk lembaga keuangan, nasabah, prasktisi, dan mahasiswa). Jakarta: PT Raja grafindo persada.

Siahaan, Hinsa. 2007. Manajemen risiko: konsep, kasus \& implementasi. Jakarta:PT. Elex Media Komputindo.

Sudarsono, Heri. 2004. Bank dan lembaga kevangan syariah. Yogyakarta: Ekonosia.

Sugiyono, Prof. Dr. 2012. Metode penelitian kuantitatif, kualitatif, dan R\&D. Bandung: Alfabeta.

Suhendi. 2002. Fiqih Muamala. Jakarta: PT. Raja Grafindo persada.

Yin, Robert K. 2009. Studi kasus : desain \& metode. Jakarta : Rajawali pers. 